\title{
Interacting effects of elevated temperature and ocean acidification on the aerobic performance of coral reef fishes
}

\author{
Philip L. Munday ${ }^{1,2, *}$, Natalie E. Crawley ${ }^{1,2}$, Göran E. Nilsson ${ }^{3}$ \\ ${ }^{1}$ ARC Centre of Excellence for Coral Reef Studies, James Cook University, Townsville 4811, Australia \\ ${ }^{2}$ School of Marine and Tropical Biology, James Cook University, Townsville 4811, Australia \\ ${ }^{3}$ Physiology Programme, Department of Molecular Biosciences, University of Oslo, PO Box 1041, 0316 Oslo, Norway
}

\begin{abstract}
Concerns about the impacts of ocean acidification on marine life have mostly focused on how reduced carbonate saturation affects calcifying organisms. Here, we show that levels of $\mathrm{CO}_{2}$-induced acidification that may be attained by 2100 could also have significant effects on marine organisms by reducing their aerobic capacity. The effects of temperature and acidification on oxygen consumption were tested in 2 species of coral reef fishes, Ostorhinchus doederleini and O. cyanosoma, from the Great Barrier Reef, Australia. The capacity for aerobic activity (aerobic scope) declined at temperatures above the summer average $\left(29^{\circ} \mathrm{C}\right)$ and in $\mathrm{CO}_{2}$-acidified water $(\mathrm{pH}$ 7.8 and $\sim 1000 \mathrm{ppm} \mathrm{CO} \mathrm{CO}_{2}$ ) compared to control water ( $\mathrm{pH}$ 8.15). Aerobic scope declined by 36 and $32 \%$ for $O$. doederleini and $O$. cyanosoma at temperatures between 29 to $32^{\circ} \mathrm{C}$, whereas it declined by 33 and $47 \%$ for $O$. doederleini and $O$. cyanosoma in acidified water compared to control water. Thus, the declines in aerobic scope in acidified water were similar to those caused by a $3^{\circ} \mathrm{C}$ increase in water temperature. Minimum aerobic scope values of $\sim 200 \mathrm{mg} \mathrm{O}_{2} \mathrm{~kg}^{-1} \mathrm{~h}^{-1}$ were attained for both species in acidified water at $32^{\circ} \mathrm{C}$, compared with over $600 \mathrm{mg} \mathrm{O}_{2} \mathrm{~kg}^{-1} \mathrm{~h}^{-1}$ in control water at $29^{\circ} \mathrm{C}$. Mortality rate increased sharply at $33^{\circ} \mathrm{C}$, indicating that this temperature is close to the lethal thermal limit for both species. Acidification further increased the mortality rate of $O$. doederleini, but not of O. cyanosoma. These results show that coral reef fishes are sensitive to both higher temperatures and increased levels of dissolved $\mathrm{CO}_{2}$, and that the aerobic performance of some reef fishes could be significantly reduced if climate change continues unabated.
\end{abstract}

KEY WORDS: Global warming - Ocean acidification - Hypercapnia - Marine fish · Metabolism · Aerobic scope

\section{INTRODUCTION}

Predicting the effects of rapid climate change on ecological communities depends on understanding the sensitivity of individuals and populations to environmental change (Harley et al. 2006, Tewksbury et al. 2008). For marine animals, a decreased capacity to perform aerobically at higher temperatures is hypothesized to be the key physiological mechanism that will determine the response of many species to climate change (Pörtner \& Knust 2007, Pörtner \& Farrell 2008).
The limited capacity of the circulatory and ventilatory systems of aquatic species to keep pace with increased $\mathrm{O}_{2}$ demands at higher temperatures causes a reduction in aerobic scope and sets the boundaries of wholeorganism thermal tolerance (Pörtner \& Knust 2007). Simultaneously, extra $\mathrm{CO}_{2}$ dissolved in the ocean due to increasing atmospheric $\mathrm{CO}_{2}$ concentrations is expected to compound the effects of higher temperatures on aerobic capacity (Pörtner \& Farrell 2008). Thus, predicting the impacts of climate change on marine organisms depends on understanding how tempera- 
ture and elevated $\mathrm{CO}_{2}$ levels interact to affect the performance of individuals (Rosa \& Seibel 2008), and ultimately how this interaction affects their capacity to sustain viable populations.

Atmospheric $\mathrm{CO}_{2}$ concentrations have increased from an estimated $280 \mathrm{ppm}$ around $1700 \mathrm{AD}$ to over $380 \mathrm{ppm}$ today, causing earth average surface temperature to increase by $\sim 0.7^{\circ} \mathrm{C}$ (Brohan et al. 2006). Depending on future $\mathrm{CO}_{2}$ emission scenarios, the average surface temperature is projected to increase by $1.1-6.4^{\circ} \mathrm{C}$ by 2100 , with best estimates placing the range between 2.0 and $4.5^{\circ} \mathrm{C}$ (Meehl et al. 2007). Average sea surface temperature increases at a slower rate than average air temperature, but is still predicted to increase by up to $3^{\circ} \mathrm{C}$ in tropical and temperate seas within the next $100 \mathrm{yr}$ (Poloczanska et al. 2007, Lough 2008, Munday et al. 2009). Although increases in average temperature may be greater in temperate regions than in the tropics, it is thought that tropical species might respond more strongly to climate change because they have evolved in a more thermally stable environment than species at higher latitudes; thus, they might be expected to have narrower thermal tolerances and to live closer to their thermal optima (Hoegh-Guldberg et al. 2007, Tewksbury et al. 2008).

Recent research has demonstrated that some coral reef fishes are sensitive to relatively small increases in maximum summer temperatures. Nilsson et al. (2009) demonstrated that the aerobic scope of 2 cardinalfish species (family Apogonidae) declined sharply with a $2^{\circ} \mathrm{C}$ increase in average summer water temperature, and Munday et al. (2008a) found that the growth of juvenile and adult spiny damselfish (family Pomacentridae) was compromised with a $3^{\circ} \mathrm{C}$ increase in average summer water temperature. Moreover, observed shifts in the geographical distributions of other marine fishes towards higher latitudes in conjunction with increases in sea temperatures (Holbrook et al. 1997, Perry et al. 2005) suggest that populations of many marine species are sensitive to small increases in ambient temperature.

As atmospheric $\mathrm{CO}_{2}$ concentrations increase, the amount of $\mathrm{CO}_{2}$ dissolved in the ocean also increases, which in turn causes ocean $\mathrm{pH}$ to decline (a process known as ocean acidification). On a 'business-asusual' A2-SRES (Special Report on Emissions Scenarios, scenario A2) emission trajectory, atmospheric $\mathrm{CO}_{2}$ concentrations are predicted to range between 730 and $1020 \mathrm{ppm}$ by 2100 (Meehl et al. 2007). This would cause ocean $\mathrm{pH}$ to drop by 0.3 to 0.4 points compared to current-day levels, making the ocean more acidic than at any time in the past 400000 yr (Feely et al. 2004). Although the combined effects of increasing water temperature and ocean acidification have been tested for a few calcifying organisms, such as corals and coralline algae (Reynaud et al. 2003, Anthony et al. 2008), their effects on the vast majority of other marine organisms, including fishes, are largely unknown (Harley et al. 2006, Fabry et al. 2008, Ishimatsu et al. 2008, Munday et al. 2008b).

In this study, we investigated the combined effects of temperature and $\mathrm{CO}_{2}$-induced ocean acidification on the aerobic scope of 2 cardinalfish species, Ostorhinchus doederleini and O. cyanosoma. These species were chosen because previous research has shown that they are sensitive to increased water temperature (Nilsson et al. 2009), but the effects of $\mathrm{CO}_{2}$-induced acidification on $\mathrm{O}_{2}$ uptake and aerobic scope are unknown. Specifically, we used respirometry to determine how increased temperature and $\mathrm{CO}_{2}$-induced ocean acidification affected the aerobic capacity of the 2 species at Lizard Island on the northern Great Barrier Reef, Australia. For each species, we measured resting $\mathrm{O}_{2}$ consumption and the maximum rate of $\mathrm{O}_{2}$ consumption while swimming at current-day average summer sea-surface temperatures experienced at Lizard Island $\left(\sim 29^{\circ} \mathrm{C}\right.$, Lough 1999) and at temperatures likely to be experienced with increasing frequency at this location over the next century $\left(31,32\right.$ and $\left.33^{\circ} \mathrm{C}\right)$. For each temperature, we tested the additional effect of ocean acidification by measuring resting and maximum $\mathrm{O}_{2}$ consumption while swimming in seawater at current-day $\mathrm{pH}$ values ( 8.15) and in seawater that had been acidified by the addition of $\mathrm{CO}_{2}$ to simulate a 0.35 unit decline in ocean $\mathrm{pH}$ by 2100 (pH 7.80 and $\sim 1000 \mathrm{ppm} \mathrm{CO}_{2}$ ).

\section{MATERIALS AND METHODS}

Experimental design. This study was conducted in January 2008 (austral summer) at Lizard Island on the northern Great Barrier Reef $\left(14^{\circ} 40^{\prime} \mathrm{S}, 145^{\circ} 28^{\prime} \mathrm{E}\right)$, Australia. Adult Ostorhinchus doederleini (1.25 to $4.01 \mathrm{~g})$ and $O$. cyanosoma (1.70 to $3.66 \mathrm{~g}$ ) were collected from the reef using a hand net after lightly anaesthetizing them with clove oil (Munday \& Wilson 1997). The fish were immediately transferred to temperature controlled indoor aquaria supplied with a continuous flow of fresh seawater pumped from the ocean. Control individuals were kept at the ambient ocean temperature, which during the experimental period was 28.5 to $29.5^{\circ} \mathrm{C}$. Treatment fish were kept in identical aquaria where water temperature was increased over a period of $24 \mathrm{~h}$ to 31,32 or $33^{\circ} \mathrm{C}\left( \pm 0.5^{\circ} \mathrm{C}\right)$ with aquarium heaters. A $12 \mathrm{~h}$ light:12 h dark light cycle was maintained with fluorescent lighting.

For each fish species, 2 replicate aquaria were kept at each temperature. One aquarium was supplied with seawater at the ambient ocean $\mathrm{pH}$ (average 8.15, range 8.02 to 8.21 ). The other aquarium at each tem- 
perature was supplied with seawater adjusted to $\mathrm{pH}$ 7.8 (range 7.75 to 7.85 ) to simulate future ocean acidification. $\mathrm{pH}$ was adjusted using the standard method of bubbling additional $\mathrm{CO}_{2}$ into a reservoir tank (Leclercq et al. 2002, Michaelidis et al. 2005, Anthony et al. 2008), which then supplied equilibrated seawater to each of the test aquaria. $\mathrm{pH}$ in the $60 \mathrm{l}$ reservoir tank was regulated with an automated $\mathrm{pH}$ controller (Tunze Aquarientechnik) connected to an electronic solenoid valve. A laboratory-grade glass $\mathrm{pH}$ probe continuously monitored $\mathrm{pH}$ in the reservoir. The solenoid injected bubbles of $\mathrm{CO}_{2}$ into a diffuser (Red Sea Reactor 500) at the bottom of the reservoir tank whenever the $\mathrm{pH}$ rose above 7.8. The diffuser rapidly dissolved $\mathrm{CO}_{2}$ into the seawater and also served as a vigorous stirrer. The equivalent atmospheric concentration of $\mathrm{CO}_{2}$ for the $\mathrm{pH}$ treatment was estimated by sealing replicate tanks in which the $\mathrm{pH}$ of the water had been adjusted and then measuring the increase in $\mathrm{pCO}_{2}$ in a narrow headspace above the water surface with an infrared $\mathrm{CO}_{2}$ probe (Vaisala). The estimated concentration of $\mathrm{CO}_{2}$ in the $\mathrm{pH}$ treatment was between 1000 and $1050 \mathrm{ppm}$. This value closely matches that of other studies that have found a 0.3 to 0.4 unit decline in seawater $\mathrm{pH}$ corresponding to $\sim 1000 \mathrm{ppm} \mathrm{CO}_{2}$ (Havenhand et al. 2008, Rosa \& Seibel 2008). Water $\mathrm{O}_{2}$ level varied between 95 and $100 \%$ of air saturation.

Seven to 13 individuals of each species were acclimated to each combination of temperature and $\mathrm{CO}_{2}$ acidification for $1 \mathrm{wk}$ prior to measurements. One week was considered sufficient because fishes rapidly became accustomed to captivity, and acclimation periods up to $3 \mathrm{wk}$ did not affect rates of $\mathrm{O}_{2}$ consumption (Nilsson unpubl. data). Furthermore, previous studies have found that compensation of blood acid-base balance of fish exposed to hypercapnia is usually stabilized within 1 to $5 \mathrm{~d}$ (Michaelidis et al. 2007). Fishes were fed twice daily to satiation with frozen blood worms and commercial fish food (INVE Aquaculture Nutrition pellets), but starved for $24 \mathrm{~h}$ before respirometry. Aquaria were checked hourly during daylight hours and any mortality recorded.

Respirometry. The methods for measuring resting $\mathrm{O}_{2}$ consumption $\left(\mathrm{MO}_{2 \text { rest }}\right.$ as described by Nilsson \& Östlund-Nilsson 2004) and maximal $\mathrm{O}_{2}$ uptake using swim respirometry $\left(\mathrm{MO}_{2 \max }\right.$ as described by Nilsson et al. 2007) followed the protocols described by Nilsson et al. (2009). Briefly, the respirometry chamber for measuring resting $\mathrm{O}_{2}$ consumption consisted of a plexiglass cylinder (internal diameter: $80 \mathrm{~mm}$ ) that could be sealed at both ends. An $\mathrm{O}_{2}$ electrode (OXI 340i, WTW) continuously recorded $\mathrm{O}_{2}$ levels within the chamber. The chamber was placed in an aquarium containing seawater at the test temperature and acidification treatment. The sides of the aquarium were covered to limit visual disturbance to fish in the chamber. At the start of a trial, a single fish was placed in the respirometer and allowed to acclimate for $2 \mathrm{~h}$ with water flowing through the chamber. Fish settled and became calm within minutes of being introduced to the chamber. Longer acclimation periods ( $24 \mathrm{~h}$ ) in the chamber did not further reduce the rate of $\mathrm{O}_{2}$ uptake in these fishes (Nilsson et al. 2009). After the acclimation period, the chamber was closed and $\mathrm{O}_{2}$ levels continuously recorded for 30 to $40 \mathrm{~min}$. All recordings were taken at $\mathrm{O}_{2}$ levels of 70 to $100 \%$ of air saturation.

Maximum $\mathrm{O}_{2}$ consumption of each individual was then tested in a respirometer where the fish was forced to swim against a water current. The swim-respirometry chamber consisted of a plexiglass cylinder with an internal diameter of $80 \mathrm{~mm}$ and a total water volume of $500 \mathrm{ml}$. The chamber could be opened at the bottom, where a petri dish was tightly fitted. The tip of an $\mathrm{O}_{2}$ electrode (same as above) was inserted $10 \mathrm{~mm}$ above the bottom of the chamber. A removable wire mesh ( $5 \mathrm{~mm}$ mesh width) was positioned horizontally in the middle of the chamber. Above the mesh, a centrally placed cylinder created a circular swim chamber, and the water was set in motion by a $6 \mathrm{~cm}$ long magnetic stirring bar in the compartment below the mesh. The respirometer was placed at the bottom of the temperature-controlled aquarium, below which a magnetic plate was placed to drive the stirring bar in the respirometer. Water speed was regulated with the magnetic stirrer. As soon as the water was set in motion, the fish started swimming against the current. Water speed was set to a point where each fish swam at or just above the aerobic maximum speed. This was achieved by increasing the water speed to a point where the fish was barely able to maintain a steady position in the chamber. Water $\mathrm{O}_{2}$ was recorded for 10 min, during which time a linear fall in $\mathrm{O}_{2}$ was observed. Recordings were taken at water $\mathrm{O}_{2}$ concentrations between 90 to $100 \%$ of air saturation.

Resting and swimming $\mathrm{O}_{2}$ consumption was tested for 6 to 8 fish at each combination of temperature (29, 31 and $32^{\circ} \mathrm{C}$ ) and $\mathrm{CO}_{2}$ acidification (control seawater \& $\mathrm{pH}$ 7.8). Respirometry was not conducted at $33^{\circ} \mathrm{C}$ because of the high mortality in the $\mathrm{CO}_{2}$-acidification treatment (Table 1). All experiments were carried out between 08:00 to 18:00 h.

Data analysis. Factorial ANOVA was used to test the effects of temperature and $\mathrm{CO}_{2}$ acidification on resting $\mathrm{O}_{2}$ consumption, maximum $\mathrm{O}_{2}$ uptake while swimming, and aerobic scope for each species. Aerobic scope was calculated as the difference between maximum swimming and resting $\mathrm{O}_{2}$ consumption. Where ANOVA revealed significant effects, Newman-Keuls multiple comparison tests were used to compare means between temperatures and between $\mathrm{CO}_{2}$ - 
acidified water and control water. Resting $\mathrm{O}_{2}$ values for Ostorhinchus cyanosoma were square root transformed prior to analysis to improve the distribution of residuals.

Logistic regression was used to test if $\mathrm{CO}_{2}$ acidification affected the probability of survival at each temperature. Analysis was conducted using Statistica version 8 .

\section{RESULTS}

\section{Aerobic capacity}

Temperature and $\mathrm{CO}_{2}$ acidification affected the $\mathrm{O}_{2}$ consumption and aerobic scope of both species of fish. Resting $\mathrm{O}_{2}$ consumption increased with increasing temperature and with $\mathrm{CO}_{2}$ acidification (Table 1, Fig. 1). For both species, resting $\mathrm{O}_{2}$ consumption in acidified water exhibited an asymptotic relationship with increasing temperature, rising significantly between 29 and $31^{\circ} \mathrm{C}$, but with no further increase from 31 to $32^{\circ} \mathrm{C}$ (Fig. 1). For Ostorhinchus doederleini, resting $\mathrm{O}_{2}$ consumption in acidified water was significantly higher than in control water at $31^{\circ} \mathrm{C}$ but not at either of the other 2 temperatures (Fig. 1a). For O. cyanosoma, resting $\mathrm{O}_{2}$ consumption in acidified water was significantly higher than in control water at $29^{\circ} \mathrm{C}$, but not at 31 or $32^{\circ} \mathrm{C}$ (Fig. 1b), resulting in a significant interaction between temperature and acidification (Table 1).

Maximum $\mathrm{O}_{2}$ consumption did not change significantly with temperature for either species (Table 1, Fig. 2). For Ostorhinchus doederleini, maximum $\mathrm{O}_{2}$

Table 1. Ostorhinchus doederleini and O. cyanosoma. ANOVA for resting oxygen consumption (resting $\mathrm{MO}_{2}$ ), maximum swimming oxygen consumption (swimming $\mathrm{MO}_{2}$ ), and aerobic scope (swimming - resting oxygen consumption) of individuals from Lizard Island at 8 combinations of water temperature $(29,31$, $\left.32,33^{\circ} \mathrm{C}\right)$ and $\mathrm{pH}(8.15,7.8)$

\begin{tabular}{|c|c|c|c|c|c|c|c|c|}
\hline \multirow[b]{2}{*}{ Source } & \multicolumn{4}{|c|}{ O. doederleini } & \multirow{2}{*}{$\overline{\mathrm{df}}$} & \multicolumn{2}{|c|}{ —O. cyanosoma } & \multirow[b]{2}{*}{$\mathrm{p}$} \\
\hline & df & MS & $F$ & $\mathrm{p}$ & & MS & $F$ & \\
\hline \multicolumn{9}{|l|}{ Resting $\mathrm{MO}_{2}$} \\
\hline Temp & 2 & 91689 & 8.89 & $<0.001$ & 2 & 135.30 & 28.67 & $<0.001$ \\
\hline $\mathrm{pH}$ & 1 & 45742 & 4.43 & 0.042 & 1 & 35.41 & 7.50 & 0.008 \\
\hline Temp $\times \mathrm{pH}$ & 2 & 18838 & 1.83 & NS & 2 & 19.26 & 4.08 & 0.02 \\
\hline Error & 35 & 10317 & & & 43 & 4.72 & & \\
\hline \multicolumn{9}{|c|}{ Swimming $\mathrm{MO}_{2}$} \\
\hline Temp & 2 & 35634 & 1.08 & NS & 2 & 4786 & 0.13 & NS \\
\hline $\mathrm{pH}$ & 1 & 74527 & 2.26 & NS & 1 & 750201 & 20.86 & $<0.001$ \\
\hline Temp $\times p H$ & 2 & 104297 & 3.16 & NS & 2 & 89444 & 2.49 & NS \\
\hline Error & 33 & 32968 & & & 43 & 35970 & & \\
\hline \multicolumn{9}{|c|}{ Aerobic scope } \\
\hline Temp & 2 & 82801 & 3.35 & 0.047 & 2 & 160580 & 4.39 & 0.018 \\
\hline $\mathrm{pH}$ & 1 & 239081 & 9.68 & 0.003 & 1 & 1184650 & 32.46 & $<0.001$ \\
\hline Temp $\times \mathrm{pH}$ & 2 & 36355 & 1.47 & NS & 2 & 46822 & 1.28 & NS \\
\hline Error & 33 & 24707 & & & 43 & 36501 & & \\
\hline
\end{tabular}

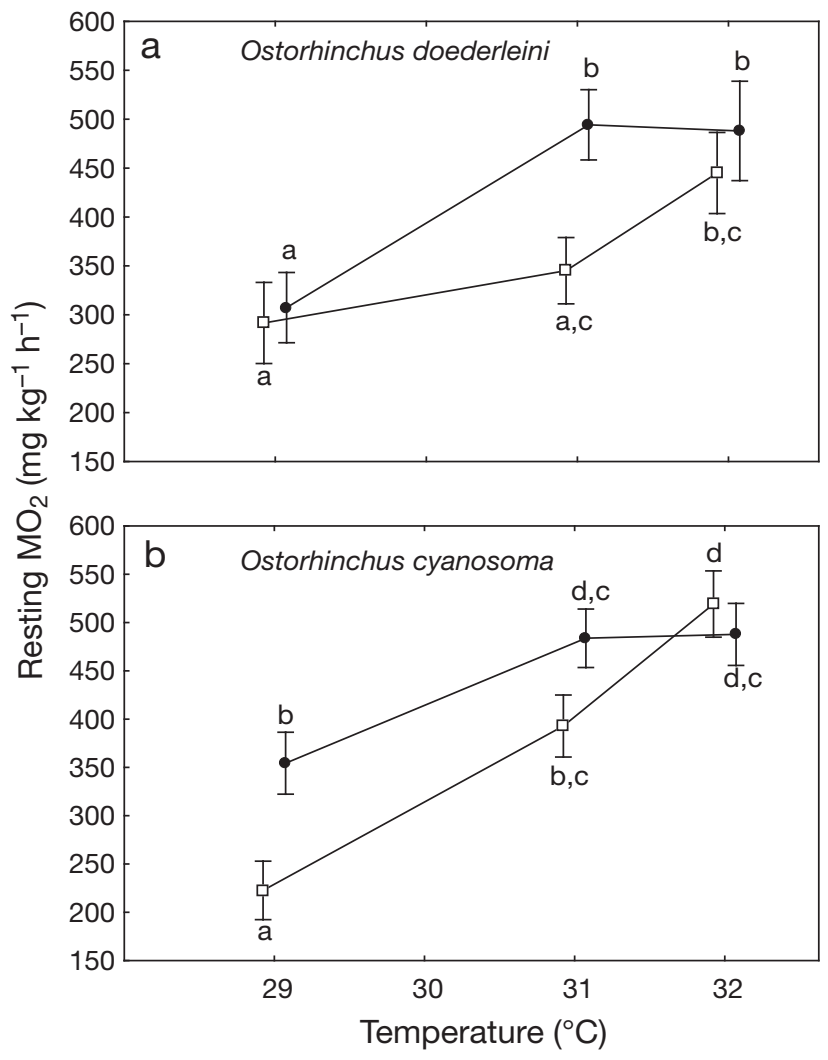

Fig. 1. (a) Ostorhinchus doederleini and (b) O. cyanosoma. Mean resting $\mathrm{MO}_{2}( \pm \mathrm{SE})$ at 6 combinations of water temperature $\left(29,31,32^{\circ} \mathrm{C}\right.$ ) and seawater $\mathrm{pH}$ (control, 7.8). ( $\square$ ) Control seawater, (๑) $\mathrm{CO}_{2}$-acidified seawater

consumption did not differ between $\mathrm{CO}_{2}$-acidified water and control water (Fig. 2a, Table 1). In contrast, maximum $\mathrm{O}_{2}$ consumption was lower for $O$. cyanosoma in $\mathrm{CO}_{2}$-acidified water than in control water (Fig. 2b, Table 1), although the mean values were only significantly different at $32^{\circ} \mathrm{C}$.

Aerobic scope decreased with both increasing temperature and $\mathrm{CO}_{2}$ acidification for both species (Table 1). There was no interaction between temperature and acidification. When temperature was considered alone, the overall mean aerobic scope of Ostorhinchus doederleini declined by $36 \%$ from $483( \pm 42) \mathrm{mg} \mathrm{O}_{2} \mathrm{~kg}^{-1} \mathrm{~h}^{-1}$ at $29^{\circ} \mathrm{C}$ to $307( \pm 56) \mathrm{mg} \mathrm{O}_{2} \mathrm{~kg}^{-1} \mathrm{~h}^{-1}$ at $32^{\circ} \mathrm{C}$. For O. cyanosoma, the mean aerobic scope declined by $32 \%$ from $609( \pm 46) \mathrm{mg} \mathrm{O}_{2}$ $\mathrm{kg}^{-1} \mathrm{~h}^{-1}$ at $29^{\circ} \mathrm{C}$ to $410( \pm 49) \mathrm{mg} \mathrm{O} \mathrm{O}_{2}$ $\mathrm{kg}^{-1} \mathrm{~h}^{-1}$ at $32^{\circ} \mathrm{C}$. The underlying reason for the decreasing aerobic scope with increasing temperature was the increase in resting $\mathrm{O}_{2}$ consumption but not in maximum $\mathrm{O}_{2}$ consumption, with 


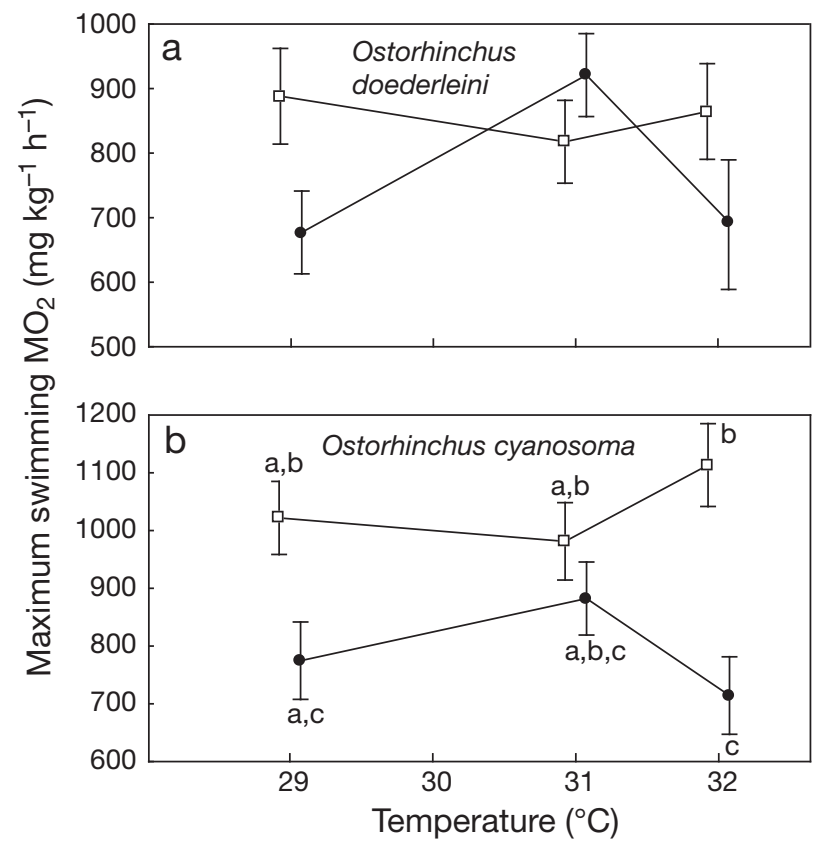

Fig. 2. (a) Ostorhinchus doederleini and (b) O. cyanosoma. Mean swimming $\mathrm{MO}_{2}( \pm \mathrm{SE})$ at 6 combinations of water temperature $\left(29,31,32^{\circ} \mathrm{C}\right.$ ) and seawater $\mathrm{pH}$ (control, 7.8 ).

$(\square)$ Control seawater, $(\bullet) \mathrm{CO}_{2}$-acidified seawater

temperature. The aerobic scope was also lower for fish kept in $\mathrm{CO}_{2}$-acidified water than for fish in control water (Table 1). When acidification was considered alone, the overall mean aerobic scope of $O$. doederleini declined by $33 \%$ from $497( \pm 35) \mathrm{mg} \mathrm{O}_{2} \mathrm{~kg}^{-1} \mathrm{~h}^{-1}$ in control water to $330( \pm 40) \mathrm{mg} \mathrm{O}_{2} \mathrm{~kg}^{-1} \mathrm{~h}^{-1}$ in acidified water. For O. cyanosoma, the mean aerobic scope declined by $47 \%$ from $661( \pm 39) \mathrm{mg} \mathrm{O}_{2} \mathrm{~kg}^{-1} \mathrm{~h}^{-1}$ in control water to $348( \pm 38) \mathrm{mg} \mathrm{O}_{2} \mathrm{~kg}^{-1} \mathrm{~h}^{-1}$ in acidified water. Therefore, the percent decline in aerobic scope in acidified water (33 to $47 \%$ ) was similar to that caused by increasing temperature from 29 to $32^{\circ} \mathrm{C}$ (32 to $36 \%$ ).

Despite the significant main effects, the only significant differences in aerobic scope for Ostorhinchus doederleini that were detected by post-hoc tests when all means were considered together were between fish in control water at $29^{\circ} \mathrm{C}$ and those in acidified water at $32^{\circ} \mathrm{C}$ (Fig. 3a). There were no significant differences in aerobic scope between fish in control water and those in acidified water within temperature treatments. In contrast, the aerobic scope for $O$. cyanosoma was significantly different between fish in control and those in acidified water at 29 and $32^{\circ} \mathrm{C}$ (Fig. 3b). The mean aerobic scope in acidified water was similar for the 2 species at each of the 4 test temperatures (Fig. 3), with minimum values of $195( \pm 91) \mathrm{mg} \mathrm{O}_{2} \mathrm{~kg}^{-1} \mathrm{~h}^{-1}$ for $O$. doederleini at $32^{\circ} \mathrm{C}$ (Fig. 3a) and $226( \pm 68) \mathrm{mg} \mathrm{O}_{2} \mathrm{~kg}^{-1}$ $\mathrm{h}^{-1}$ for O. cyanosoma at $32^{\circ} \mathrm{C}$ (Fig. $3 \mathrm{~b}$ ).

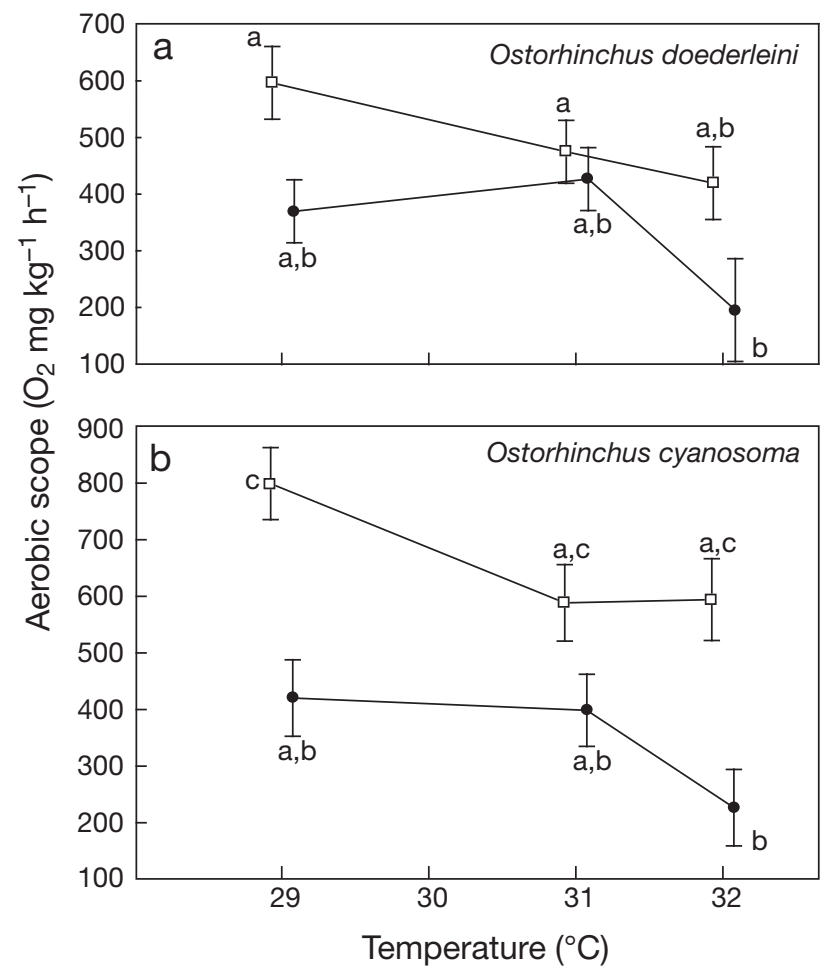

Fig. 3. (a) Ostorhinchus doederleini and (b) O. cyanosoma. Mean aerobic scope $( \pm \mathrm{SE})$ at 6 combinations of water temperature $\left(29,31,32^{\circ} \mathrm{C}\right)$ and seawater $\mathrm{pH}$ (control, 7.8$)$. ( $\square$ ) Control seawater, $(\bullet) \mathrm{CO}_{2}$-acidified seawater

\section{Mortality}

There was no mortality in either species at 29, 31 or $32^{\circ} \mathrm{C}$ in control water and only a small number of fish died at these temperatures in acidified water (Table 2; 4 of 34 Ostorhinchus doederleini and 2 of $27 O$. cyanosoma). In contrast, over $1 / 3$ of individuals from both species died within a week in control water at $33^{\circ} \mathrm{C}$ (3 of 8 O. doederleini and 4 of 9 O. cyanosoma). This indicates that $33^{\circ} \mathrm{C}$ is close to the lethal thermal limit of both species at Lizard Island. $\mathrm{CO}_{2}$ acidification significantly increased mortality of $O$. doederleini (Wald $=8.41, \mathrm{p}=0.004$ ), but did not affect the mortality rate of $O$. cyanosoma (Wald $=0.87, \mathrm{p}=0.35$ ). Four of $12 \mathrm{O}$. doederleini died in $\mathrm{CO}_{2}$-acidified water at $32^{\circ} \mathrm{C}$ and all of them died in acidified water at $33^{\circ} \mathrm{C}$ (Table 2).

\section{DISCUSSION}

Aerobic function affects all aspects of individual performance and, thus ultimately, population sustainability. We found that both increased temperature and $\mathrm{CO}_{2}$-induced acidification reduced the aerobic scope of 2 common coral reef fish species. Aerobic scope 
Table 2. Ostorhinchus doederleini and O. cyanosoma. Number and percent (in parenthesis) of individuals from Lizard Island that died when kept at 8 combinations of water temperature $\left(29,31,32,33^{\circ} \mathrm{C}\right)$ and $\mathrm{pH}(8.15,7.8)$ for $1 \mathrm{wk}$

\begin{tabular}{|lcccc|}
\hline \multirow{2}{*}{$\begin{array}{l}\text { Temperature } \\
\left({ }^{\circ} \mathrm{C}\right)\end{array}$} & \multicolumn{5}{c|}{ Species and seawater pH } \\
& $\begin{array}{l}\text { O. doederleini } \\
\text { 8.15 }\end{array}$ & 7.80 & 8.15 & 7.80 \\
\hline 29 & 0 & 0 & 0 & $1(11.1)$ \\
31 & 0 & 0 & 0 & 0 \\
32 & 0 & $4(33.3)$ & 0 & $1(11.1)$ \\
33 & $3(37.5)$ & $13(100)$ & $4(44.4)$ & $3(33.3)$ \\
\hline
\end{tabular}

decreased with increasing temperature, as has been previously described (Nilsson et al. 2009). Importantly, acidification had an additional effect that further reduced aerobic scope, and the percent declines in aerobic scope in acidified water (equivalent to 1000 ppm atmospheric $\mathrm{CO}_{2}$ ) were of a similar magnitude to the declines caused by a $3^{\circ} \mathrm{C}$ increase in water temperature above summer averages. Increasing levels of atmospheric $\mathrm{CO}_{2}$ over the coming century will act to both increase average global temperatures and acidify the ocean (Meehl et al. 2007). A fall in aerobic scope with increasing temperature is thought to be the key physiological mechanism determining how most marine species will be affected by climate change, setting the limits for species distributions and causing range shifts (Pörtner \& Knust 2007). Our results suggest that the aerobic capacity of some species will be further compromised by the effects of additional $\mathrm{CO}_{2}$ dissolved in seawater as atmospheric $\mathrm{CO}_{2}$ continues to rise. Consequently, levels of atmospheric $\mathrm{CO}_{2}$ that could be attained by 2100 could have significant impacts on the success of some marine fishes by reducing their capacity for aerobic activity.

The effects on aerobic scope observed here could have been due to the direct effects of an elevated $\mathrm{CO}_{2}$ level $(\sim 1000 \mathrm{ppm})$, the reduced seawater $\mathrm{pH}(0.35$ units), or a combination of both. It is likely that hypercapnia played a significant role because $\mathrm{CO}_{2}$ readily diffuses across fish gills where it acts to acidify the blood and other tissues (Ishimatsu et al. 2005, 2008, Pörtner et al. 2005). Reduced seawater $\mathrm{pH}$ will also acidify blood and tissue, but is expected to act more slowly. Bicarbonate accumulation and active ion transport are used by fish to compensate for increasing acidosis and to regulate their acid-base balance (Claiborne et al. 2002). However, these mechanisms are likely to have some physiological cost. Furthermore, elevated tissue $\mathrm{pCO}_{2}$ may hinder the effective transport of $\mathrm{O}_{2}$, especially in species or life stages with high metabolic demands (Pörtner et al. 2005). Whatever specific mechanisms were responsible for the reduction in aerobic scope we observed, our experiments show that continued $\mathrm{CO}_{2}$-induced acidification of the ocean could affect the aerobic capacity of some marine fishes, and thus potentially influence the sustainability of local populations.

The underlying reason for the reduced aerobic scope in $\mathrm{CO}_{2}$-acidifed water for the 2 species tested here was that resting $\mathrm{O}_{2}$ consumption either increased or remained stable in acidified water compared to control water (Fig. 1), whereas maximum $\mathrm{O}_{2}$ consumption either decreased or remained stable in acidified water compared to control water (Fig. 2). This effect was more apparent in Ostorhinchus cyanosoma, which exhibited a larger percent decline in aerobic scope than O. doederleini. Although increased $\mathrm{CO}_{2}$ often causes metabolic depression in marine invertebrates (Pörtner et al. 2004, Michaelidis et al. 2005, Rosa \& Seibel 2008), similar effects are not usually observed in fish. Instead, resting $\mathrm{O}_{2}$ consumption of fish is usually unaffected by hypercapnia (Pörtner et al. 2004, Ishimatsu et al. 2005, 2008). This indicates that fish are generally able to meet $\mathrm{O}_{2}$ demands when exposed to elevated $\mathrm{CO}_{2}$ levels provided that no exercise is necessary (Ishimatsu et al. 2005). We observed small increases in resting $\mathrm{O}_{2}$ consumption for both species of coral reef fishes studied here, even after a week of acclimation; this suggests some energetic cost involved in acid-base compensation for these species, even under the relatively low levels of hypercapnia used in our experiments.

While resting $\mathrm{O}_{2}$ consumption tended to increase slightly in $\mathrm{CO}_{2}$-acidifed water, maximum $\mathrm{O}_{2}$ consumption during swimming was unaffected in Ostorhinchus doederleini and reduced in O. cyanosoma. Decreased $\mathrm{O}_{2}$ consumption during swimming under hypercapnic conditions has been observed in other fishes (Ishimatsu et al. 2005), but only at levels of ambient $\mathrm{CO}_{2}$ that are much greater than used in our experiments to simulate ocean acidification. The significant decline in maximum swimming $\mathrm{O}_{2}$ consumption for O. cyanosoma exposed to water acidified with $\sim 1000 \mathrm{ppm} \mathrm{CO}_{2}$ demonstrates that this species is especially sensitive to even small increases in ambient $\mathrm{CO}_{2}$. This is reflected in the greater percent decrease in the aerobic scope of O. cyanosoma ( $47 \%$ ) compared with O. doederleini $(33 \%)$ in acidified water.

The sensitivity to $\mathrm{CO}_{2}$ acidification displayed by the 2 species of coral reef cardinalfish has to our knowledge not been documented in other physiological studies on fish. Fishes are usually regarded as being relatively tolerant to a wide range of dissolved $\mathrm{CO}_{2}$ levels and water $\mathrm{pH}$ (Ishimatsu et al. 2005, Pörtner et al. 2004, 2005). This is probably because most previous studies on $\mathrm{pH}$ and $\mathrm{CO}_{2}$ effects on fish had been done on temperate species or tropical freshwater species that are adapted to habitats with large natural variations in $\mathrm{CO}_{2}$ and acidity levels (Freda \& McDonald 1988, Mor- 
ris et al. 1989, Ishimatsu et al. 2005). For example, the rainbow trout Oncorhynchus mykiss not only lives in both freshwater and seawater, but also tolerates $\mathrm{pH}$ values from 6 to 9 without any measurable negative effects on physical performance (Randall \& Brauner 1991, Morgan et al. 2001). In contrast, coral reef fishes do not experience such substantial changes in $\mathrm{CO}_{2}$ and $\mathrm{pH}$ levels, which may make them more sensitive to changes in these environmental parameters. In a previous study, Nilsson et al. (2009) found that the aerobic performance of the 2 cardinalfish species studied here was more strongly affected by changes in environmental conditions (temperature) than a number of other coral reef fishes. Therefore, although coral reef fishes might be expected to be more sensitive to changes in $\mathrm{CO}_{2}$ and $\mathrm{pH}$ than other fishes, we expect that the responses of Ostorhinchus doederleini and $O$. cyanosoma to acidification would be towards the extremes exhibited by coral reef fishes. Further studies are now needed to determine whether the effect of ocean acidification on the aerobic performance of the 2 cardinalfishes observed here is representative of other coral reef species or not.

In one of the few other studies testing the effects of moderately low levels of hypercapnia on marine fish, Michaelidis et al. (2007) observed changes in enzyme activity consistent with a shift from aerobic to anaerobic activity in gilthead bream (Sparus aurata) exposed to seawater where $\mathrm{pH}$ had been decreased by 0.75 of a unit (8.05 to 7.3) through the addition of $\mathrm{CO}_{2}$. Such shifts in metabolic pathways are expected to have energetic costs and could affect individual performance. Although the reduction in $\mathrm{pH}$ used by Michaelidis et al. (2007) was twice that used in our experiments, the equivalent $\mathrm{CO}_{2}$ levels $(4.5 \times$ ambient) were still much less than those used in most previous studies on hypercapnia in marine fishes (Ishimatsu et al. 2005, 2008) and illustrate that low to moderate levels of hypercapnia can have physiological consequences for some marine fishes. Similar effects on metabolic pathways might have been responsible for the reduced aerobic scope we observed in Ostorhinchus doederleini and O. cyanosoma.

Natural seawater $\mathrm{pH}$ at Lizard Island varied from a minimum of 8.08 to a maximum of 8.21 over the course of our experiments, with minimum values usually attained during the early morning. $\mathrm{pH}$ may decline in shallow reef habitats overnight due to the effect of accumulating $\mathrm{CO}_{2}$ from respiration of reef organisms and values below 8.00 have been recorded at some locations (Ohde \& van Woesik 1999, Kuffner et al. 2008). Therefore, reef fishes might already be exposed to elevated $\mathrm{CO}_{2}$ and $\mathrm{pH}$ values approaching 7.8, especially if they shelter in the reef matrix overnight. However, regular tidal flushing of shallow reef water and photosynthesis by reef algae and corals during day- light hours would mean that elevated $\mathrm{CO}_{2}$ and low $\mathrm{pH}$ values are temporary. The intermittent nature of low $\mathrm{pH}$ episodes in coral reefs may explain why the cardinalfishes we tested were sensitive to continued exposure to $\mathrm{CO}_{2}$ acidification for a week even though $\mathrm{pH}$ values of 7.8 may already occur in some reef habitats.

Mortality of both cardinalfish species increased markedly at $33^{\circ} \mathrm{C}$. Although $29^{\circ} \mathrm{C}$ is the average summer sea temperature at Lizard Island, maximum temperatures already exceed $30^{\circ} \mathrm{C}$ and extremes of up to $32.7^{\circ} \mathrm{C}$ have been recorded at this location (Lough 1999). Sea surface temperatures are predicted to increase by 1 to $3^{\circ} \mathrm{C}$ over the next 50 to 100 yr as a result of global warming (Lough 2008, Munday et al. 2009). Therefore, temperatures near $33^{\circ} \mathrm{C}$ will be experienced with greater frequency over the coming century. However, acute mortality at extreme temperatures is unlikely to be the primary threat to these species, or other coral reef fishes. The reduced capacity for aerobic function associated with moderate increases in temperature is likely to affect key aspects of individual performance, including feeding, growth and reproduction, and therefore threatens population sustainability before conditions become lethal to short-term individual survival.

Mortality of Ostorhinchus doederleini at elevated temperatures was exacerbated by high $\mathrm{CO}_{2}$ and low $\mathrm{pH}$, with all individuals dying within a week at $33^{\circ} \mathrm{C}$ in acidified water. This suggests that the physiological condition of individuals was already severely compromised at $33^{\circ} \mathrm{C}$ and that the additional stress of hypercapnia was sufficient to cause increased mortality. $O$. doederleini has an anti-tropical distribution (Randall et al. 1991), which suggests that it is cannot tolerate temperatures above $30^{\circ} \mathrm{C}$ that already occur in equatorial regions. Our results indicate that ocean acidification will further limit the low latitude locations where this species can persist in the future.

To date, studies on the effects of additional $\mathrm{CO}_{2}$ in tropical seas has mostly focused on the effects of reduced carbonate saturation states on calcifying organisms (e.g. Kleypas et al. 2006, Anthony et al. 2008). This study shows that levels of atmospheric $\mathrm{CO}_{2}$ that could be attained by 2100 could also have significant impacts on the success of some tropical marine fishes by reducing their capacity for aerobic activity. This supports recent suggestion that ocean acidification poses a significant physiological challenge to some sea animals, particularly when coupled with rising water temperature (Pörtner et al. 2005, Pörtner \& Farrell 2008, Rosa \& Seibel 2008). The capacity for aerobic activity underpins the sustainability of animal populations, and thus determines the locations where species can persist. Whether populations of fishes or other reef organisms can adapt to permanent acidification is unknown, but should be a priority area for further research. 
Acknowledgements. Staff at the Lizard Island Research Station provided excellent logistical support. This research was supported by the Australian Research Council, the Research Council of Norway, James Cook University, and the University of Oslo.

\section{LITERATURE CITED}

Anthony KRN, Kline DI, Diaz-Pulido G, Hoegh-Guldberg O (2008) Ocean acidification causes bleaching and productivity loss in coral reef builders. Proc Natl Acad Sci USA 105:17442-17446

Brohan P, Kennedy JJ, Harris I, Tett SFB, Jones PD (2006) Uncertainty estimates in regional and global observed temperature changes: a new dataset from 1850. J Geophys Res 111:D12106

Claiborne JB, Edwards SL, Morrison-Shetlar AI (2002) Acidbase regulation in fishes: cellular and molecular mechanisms. J Exp Zool 293:302-319

Fabry VJ, Seibel BA, Feely RA, Orr JC (2008) Impacts of ocean acidification on marine fauna and ecosystem processes. ICES J Mar Sci 65:414-432

Feely RA, Sabine CL, Lee K, Berelson W, Kleypas J, Fabry VJ, Millero FJ (2004) Impact of anthropogenic $\mathrm{CO}_{2}$ on the $\mathrm{CaCO}_{3}$ system in the oceans. Science 305:362-366

Freda J, McDonald DG (1988) Physiological correlates of interspecific variation in acid tolerance in fish. J Exp Biol 136: 243-258

Harley CDG, Hughes AR, Hultgren KM, Miner BG and others (2006) The impacts of climate change in coastal marine systems. Ecol Lett 9:228-241

Havenhand JN, Buttler FR, Thorndyke MC, Williamson JE (2008) Near-future levels of ocean acidification reduce fertilization success in a sea urchin. Curr Biol 18:R651-R652

Hoegh-Guldberg O, Mumby PJ, Hooten AJ, Steneck RS and others (2007) Coral reefs under rapid climate change and ocean acidification. Science 318:1737-1742

> Holbrook SJ, Schmitt RJ, Stephens JS (1997) Changes in an assemblage of temperate reef fishes associated with a climate shift. Ecol Appl 7:1299-1310

Ishimatsu A, Hayashi M, Lee KS, Kikkawa T, Kita J (2005) Physiological effects on fishes in a high- $\mathrm{CO}_{2}$ world. J Geophys Res 110:C09S09 doi:101029/2004JC002564

Ishimatsu A, Hayashi M, Kikkawa T (2008) Fishes in high- $\mathrm{CO}_{2}$ acidified oceans. Mar Ecol Prog Ser 373:295-302

Kleypas JA, Feely RA, Fabry VJ, Langdon C, Sabine CL, Robbins LL (2006) Impacts of ocean acidification on coral reefs and other marine calcifiers: a guide for future research. NSF, NOAA and the US Geological Survey, St Petersburg, FL

Kuffner IB, Andersson AJ, Jokiel PL, Rodgers KS, MacKenzie FT (2008) Decreased abundance of crustose coralline algae due to ocean acidification. Nature Geosci 1:114-117

Leclercq N, Gattuso JP, Jaubert J (2002) Primary production, respiration, and calcification of a coral reef mesocosm under increased $\mathrm{CO}_{2}$ partial pressure. Limnol Oceanogr 47:558-564

Lough JM (1999) Sea surface temperatures on the Great Barrier Reef: a contribution to the study of coral bleaching. GBRMPA Research Publication 57, Great Barrier Reef Marine Park Authority, Townsville

Lough JM (2008) Shifting climate zones for Australia's tropical marine zones. Geophys Res Lett 35:L14708 doi:101029/ 2008GL034634

Meehl GA, Stocker TF, Collins WD, Friedlingstein P and others (2007) Global climate projections. In: Solomon S, Qin D, Manning M, Chen Z and others (eds) Climate change 2007: the physical science basis. Cambridge University Press, Cambridge, UK, p 686-688

Michaelidis B, Ouzounis C, Paleras A, Pörtner HO (2005) Effects of long-term moderate hypercapnia on acid-base balance and growth rate in marine mussels Mytilus galloprovincialis. Mar Ecol Prog Ser 293:109-118

Michaelidis B, Spring A, Pörtner HO (2007) Effects of long-term acclimation to environmental hypercapnia on extracellular acid-base status and metabolic capacity in Mediterranean fish Sparus aurata. Mar Biol 150:1417-1429

> Morgan IJ, McDonald DG, Wood CM (2001) The cost of living for freshwater fish in a warmer, more polluted world. Glob Change Biol 7:345-355

Morris R, Taylor EW, Brown DJA, Brown JA (1989) Acid toxicity and aquatic animals. Cambridge University Press, Cambridge, UK

Munday PL, Wilson SK (1997) Comparative efficacy of clove oil and other chemicals in anaesthetisation of Pomacentrus amboinensis, a coral reef fish. J Fish Biol 51:931-938

Munday PL, Kingsford M, O'Callaghan M, Donelson JM (2008a) Elevated temperature restricts growth potential of the coral reef fish Acanthochromis polyacanthus. Coral Reefs 27:927-931

Munday PL, Jones GP, Pratchett MS, Williams AJ (2008b) Climate change and the future for coral reef fishes. Fish Fish 9: 261-285

Munday PL, Leis JM, Lough JM, Paris CB, Kingsford MJ, Berumen ML, Lambrechts J (2009) Climate change and coral reef connectivity. Coral Reefs 28:379-395

> Nilsson GE, Östlund-Nilsson S (2004) Hypoxia in paradise: widespread hypoxia tolerance in coral reef fishes. Proc R Soc Lond B 271:S30-S33

Nilsson GE, Ostlund-Nilsson S, Penfold R, Grutter AS (2007) From record performance to hypoxia tolerance: respiratory transition in damselfish larvae settling on a coral reef. Proc R Soc Lond B Biol Sci 274:79-85

Nilsson GE, Crawley N, Lunde IG, Munday PL (2008) Elevated temperature reduces the respiratory scope of coral reef fishes. Global Change Biol 15:1405-1412

Ohde S, vanWoesik R (1999) Carbon dioxide flux and metabolic processes of a coral reef Okinawa. Bull Mar Sci 65:559-576

Perry AL, Low PJ, Ellis JR, Reynolds JD (2005) Climate change and distribution shifts in marine fishes. Science 308:1912-1915

Poloczanska ES, Babcock RC, Butler A, Hobday A and others (2007) Climate change and Australian marine life. Oceanogr Mar Biol Annu Rev 45:407-478

Pörtner HO, Farrell AP (2008) Physiology and climate change. Science 322:690-692

> Pörtner HO, Knust R (2007) Climate change affects marine fishes through the oxygen limitation of thermal tolerance. Science 315:95-97

Pörtner HO, Langenbuch M, Reipschlager A (2004) Biological impact of elevated ocean $\mathrm{CO}_{2}$ concentrations: lessons from animal physiology and earth history. J Oceanogr 60:705-718

Pörtner HO, Langenbuch M, Michaelidis B (2005) Synergistic effects of temperature extremes, hypoxia, and increases in $\mathrm{CO}_{2}$ on marine animals: from Earth history to global change. J Geophys Res 110:C09S10 doi:101029/2004JC002561

Randall D, Brauner C (1991) Effects of environmental factors on exercise in fish. J Exp Biol 160:113-126

Randall JE, Allen GR, Steene RC (1991) Fishes of the Great Barrier Reef and Coral Sea. Crawford House Press, Bathurst, Australia

Reynaud S, Leclercq N, Romaine-Lioud S, Ferrier-Pages C, Jaubert J, Gattuso JP (2003) Interacting effects of $\mathrm{CO}_{2}$ partial pressure and temperature on photosynthesis and calcification in a scleractinian coral. Glob Change Biol 9:1660-1668

> Rosa R, Seibel BA (2008) Synergistic effects of climate-related variables suggest future physiological impairment in a top oceanic predator. Proc Natl Acad Sci USA 105:20776-20780

Tewksbury JJ, Huey RB, Deutsch CA (2008) Putting the heat on tropical animals. Science 320:1296-1297 